\title{
Front Matter Volume 9485
}

"Front Matter Volume 9485," Proc. SPIE 9485, Thermosense: Thermal Infrared Applications XXXVII, 948501 (10 June 2015); doi:

$10.1117 / 12.2199297$

SPIE Event: SPIE Sensing Technology + Applications, 2015, Baltimore, MD, United SPIE. States 


\title{
PROCEEDINGS OF SPIE
}

\section{Thermosense: Thermal Infrared Applications XXXVII}

\author{
Sheng-Jen (Tony) Hsieh \\ Joseph N. Zalameda \\ Editors
}

20-23 April 2015

Baltimore, Maryland, United States

Sponsored and Published by

SPIE 
The papers included in this volume were part of the technical conference cited on the cover and title page. Papers were selected and subject to review by the editors and conference program committee. Some conference presentations may not be available for publication. The papers published in these proceedings reflect the work and thoughts of the authors and are published here in as submitted. The publisher is not responsible for the validity of the information or for any outc omes resulting from reliance thereon.

Please use the following format to cite material from this book:

Author(s), "Title of Paper," in Thermosense: Thermal Infrared Applications XXXVII, edited by Sheng-J en (Tony) Hsieh, J oseph N. Zalameda, Proceed ings of SPIE Vol. 9485 (SPIE, Belling ham, WA, 2015) Article CID Number.

ISSN: 0277-786X

ISBN: 9781628416015

Published by

SPIE

P.O. Box 10, Bellingham, Washington 98227-0010 USA

Telephone +1 3606763290 (Pacific Time)· Fax +1 3606471445

SPIE.org

Copyright @2015, Soc iety of Photo-O ptic al Instrumentation Engineers.

Copying of material in this book for intemal or personal use, or for the intemal or personal use of specific clients, beyond the fa ir use provisions granted by the U.S. Copyright Law is authorized by SPIE subject to payment of copying fees. The Transactional Reporting Service base fee for this volume is $\$ 18.00$ per article (or portion thereof), which should be paid directly to the Copyright Clearance Center (CCC), 222 Rosewood Drive, Danvers, MA 01923. Payment may also be made electronically through CCC Online at copyright.com. Other copying for republication, resale, advertising or promotion, or any form of systematic or multiple reproduction of a ny material in this book is prohibited except with permission in writing from the publisher. The CCC fee code is $0277-786 \times / 15 / \$ 18.00$.

Printed in the United States of America.

Public ation of record for individual papers is online in the SPIE Dig ital Library.

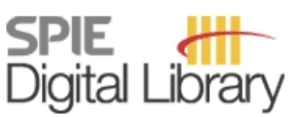

SPIEDigitalLibrary.org

Paper Numbering: Proc eedings of SPIE follow an e-First public ation model, with papers published first online and then in print. Papers are published as they are submitted and meet publication criteria. A unique citation identifier (CID) number is assigned to each article at the time of the first publication. Utilization of CIDs allows articles to be fully citable as soon as they are published online, and connects the same identifier to all online, print, and electronic versions of the publication. SPIE uses a six-dig it CID article numbering system in which:

- The first four digits correspond to the SPIE volume number.

- The last two digits indic ate publication order within the volume using a Base 36 numbering system employing both numerals and letters. These two-number sets start with $00,01,02,03,04$, $05,06,07,08,09,0 A, 0 B \ldots$ 0Z, followed by 10-1Z, 20-2Z, etc.

The CID Number appears on each page of the manuscript. The complete citation is used on the first page, and an abbreviated version on subsequent pages. 


\title{
Contents
}

\author{
vii Authors \\ ix Conference Committees \\ xiii Introduction
}

\section{SESSION 1 AEROSPACE APPLICATIONS}

948502 Real time fatigue damage growth assessment of a composite three-stringer panel using passive thermography (Invited Paper) [9485-1]

948503 Nondestructive evaluation of aircraft coatings with infrared diffuse reflectance spectra [9485-2]

948504 Comparative evaluation of aerospace composites using thermography and ultrasonic NDT techniques [9485-3]

948505 A new approach on JPSS VIIRS BCS and SVS PRT calibration [9485-4]

948506 Integration of infrared and optical imaging techniques for the nondestructive inspection of aeronautic parts [9485-6]

\section{SESSION 2 BUILDING MATERIALS AND INFRASTRUCTURE APPLICATIONS I}

948507 Practical identification of moisture sources in building assemblies using infrared thermography [9485-7]

948508 Evaluation of angle dependence in spectral emissivity of ceramic tiles measured by FT-IR [9485-8]

948509 Study of experimental parameters for IRT applications in building elements using multilayered analytical solutions [9485-9]

9485 OA Active infrared thermographic testing with distance heating [9485-10]

\section{SESSION 3 BUILDING MATERIALS AND INFRASTRUCTURE APPLICATIONS II}

9485 OB Comparison of lock-in and pulse-phase thermography for defect characterization in FRP composites applied to concrete [9485-11]

9485 OC Crack depth determination with inductive thermography [9485-12] 
9485 OD Measurement of flaw size from thermographic data [9485-13]

$9485 \mathrm{OH}$ Temperature measurements on solid surfaces in rack-storage fires using IR thermography [9485-19]

$9485 \mathrm{Ol}$ Comparison of step heating and modulated frequency thermography for detecting bubble defects in colored acrylic glass [9485-16]

9485 0J Detection of pinhole defects in optical film using thermography and artificial neural network [9485-17]

\section{SESSION 4 DETECTOR AND SENSORY SYSTEM DEVELOPMENT}

9485 OK Advances in infrared fibers (Invited Paper) [9485-20]

$9485 \mathrm{OL} \quad$ Logarithmic InGaAs detectors with global shutter and active dark current reduction [9485-21]

$94850 \mathrm{M}$ The fabrication of sub-micron size cesium iodide $x$-ray scintillator [9485-22]

9485 ON Swap intensified WDR CMOS module for I2/LWIR fusion [9485-23]

948500 Highly sensitive arrayed indium-antimony nanowires for infrared detection [9485-24]

9485 OP Computational methods for improving thermal imaging for consumer devices [9485-25]

\section{SESSION $5 \quad$ NDT AND SIGNAL PROCESSING}

$94850 Q$ Pulsed thermal NDT in tables, figures, and formulas (Invited Paper) [9485-26]

9485 OR Advances in thermographic signal reconstruction (Invited Paper) [9485-27]

9485 OS Principal component analysis of thermographic data (Invited Paper) [9485-28]

9485 OT Review of pulsed phase thermography (Invited Paper) [9485-29]

$9485 \mathrm{OV}$ A novel data processing algorithm in thermal property measurement and defect detection by using one-sided active infrared thermography [9485-31]

\section{SESSION 6 NDT AND MATERIALS EVALUATION I}

$94850 X \quad$ Infrared thermography and ultrasound C-scan for non-destructive evaluation of 3D carbon fiber materials: a comparative study (Best Student Paper Award) [9485-33]

9485 OY Characterization of phononic heterostructures by infrared thermography [9485-34] 
$9485 \mathrm{OZ}$ Superimpose methods for uncooled infrared camera applied to the micro-scale thermal characterization of composite materials [9485-35]

948511 Characterization of nuclear graphite elastic properties using laser ultrasonic methods [9485-37]

948512 Thermal diffusivity estimation with quantitative pulsed phase thermography [9485-46]

\section{SESSION 7 MANUFACTURING AND PROCESSING INDUSTRIES}

$948513 \quad$ IR-based spot weld NDT in automotive applications [9485-38]

948514 Laser beam welding quality monitoring system based in high-speed ( $10 \mathrm{kHz}$ ) uncooled MWIR imaging sensors [9485-39]

948515 Comparison of the insulation property of an innovative material and a traditional one by infrared thermography [9485-40]

948516 Thermographic investigation of luminescent barium borate glasses for white-LED applications [9485-41]

948517 About infrared scanning of photovoltaic solar plant [9485-42]

\section{SESSION 8 NDT AND MATERIALS EVALUATION II}

948519 Three-dimensional non-destructive testing (NDT) in the infrared spectrum [9485-44]

$94851 \mathrm{~A}$ Thermographic inspection of external thermal insulation systems with mechanical fixing [9485-45]

9485 IB Analysis of the relative merits of the 3-5 $\mu \mathrm{m}$ and the 8-12 $\mu \mathrm{m}$ spectral bands using detected thermal contrast [9485-47]

\section{SESSION 9 DETECTION OF GAS AND LEAKS}

9485 1C Time-resolved multispectral imaging of combustion reaction [9485-48]

9485 ID Thermal imaging of microfluidic systems as a model for investigating energy efficiency [9485-49]

$9485 \mathrm{IF} \quad$ Gas and flame detection and identification using uncooled MWIR imaging sensors [9485-51]

9485 IG Detection of seal contamination in heat-sealed food packaging based on active infrared thermography (Best Paper Award) [9485-52] 
$9485 \mathrm{1H}$ Observation of temperature trace, induced by changing of temperature inside the human body, on the human body skin using commercially available IR camera [9485-53]

$948511 \quad$ Mass screening for infectious disease containment and pandemic outbreaks: misconceptions [9485-54]

$94851 \mathrm{~J}$ 3D medical thermography device [9485-55] 


\section{Authors}

Numbers in the index correspond to the last two digits of the six-digit citation identifier (CID) article numbering system used in Proceedings of SPIE. The first four digits reflect the volume number. Base 36 numbering is employed for the last two digits and indicates the order of articles within the volume. Numbers start with 00, 01, 02, 03, 04, 05, 06, 07, 08, 09, OA, OB...0Z, followed by 10-12, 20-2Z, etc.

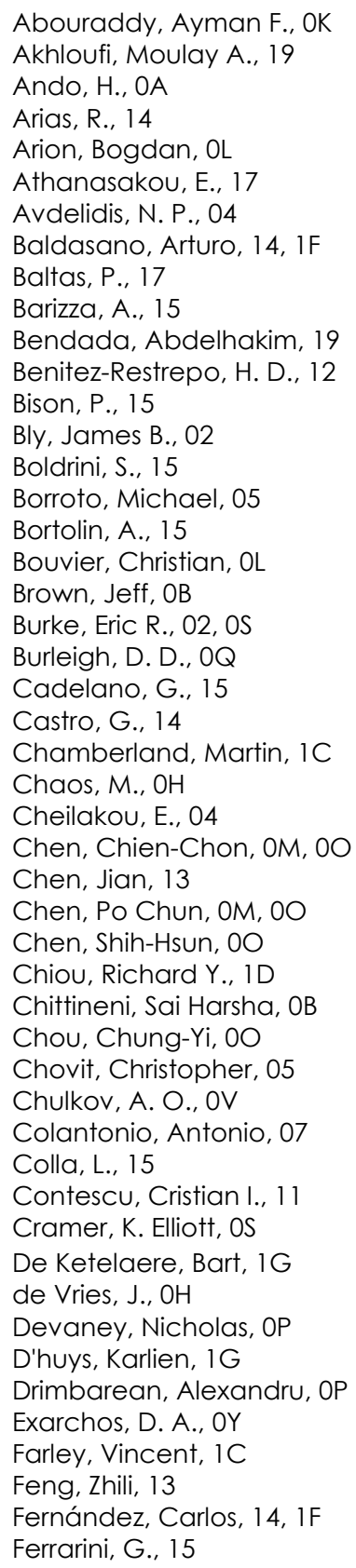

Florez-Ospina, Juan F., 12

Frendberg Beemer, Maria, OR

Gagnon, Marc-André, $1 \mathrm{C}$

Gallego, Nidia C., 11

Genest, Marc, OX

Gómez, Luis, 14, $1 \mathrm{~F}$

González-Camino, María, 14, $1 F$

Gross, Kevin C, 03

Gutiérrez, Raúl, 14, $1 \mathrm{~F}$

Guyon, Yannis, 19

Guyot, Éric, 1C

Han, Karen, 11

Hatziioannidis, I., 04

Hawks, Michael R., 03

Horne, Michael R., 02

Howell, Patricia A., OD, OS

Hsieh, Sheng-Jen, OI, OJ, 00

Huang, Ker Jer, OM

Hun, Chien Wan, OM

Huot, Alexandrine, 1C

Ibarra-Castanedo, Clemente, 06, OT, 19

Jahjah, Karl-Alexandre, 1C

Joncas, Simon, OX

Jones, Christopher M., 05

Kamarajugadda, Pranav Ram, ID

Kauppinen, T., 17

Kikuchi, T., 08

Kobayashi, C., 08, 0A

Korth, Hans G., 03

Kovi, M., 04

Lagueux, Philippe, 1C

Lapido, Y., 14

Leando, Peter, 11

Leduc, Catherine, $0 \mathrm{X}$

Linares, Rodrigo, 14, $1 \mathrm{~F}$

Liu, Changchun, 1D

López, F., 06

Lynch, Colm N., OP

Maldague, Xavier, P., 06, OT, OX, 12

Marcotte, Fréderick, $1 \mathrm{C}$

Marini, R., 04

Marschke, Steve, 05

Matikas, T. E., OY

Mauk, Michael G., ID

Mclntosh, Gregory B., 07

Moghadam, Peyman, $1 \mathrm{~J}$

Morikawa, Junko, $\mathrm{OZ}$

$\mathrm{Ni}$, Yang, OL, ON

Nikopoulous, B., 17 
Noguier, Vincent, OL, ON

Nolte, Peter W., 16

Ogasawara, N., 08, 0A

Olasov, Lauren R., 11

Ospina-Borras, J. E., 12

Oswald-Tranta, B., OC

Panouillot, P.-E., 17

Paoletti, D., 06

Psarobas, I., OY

Ren, N., $\mathrm{OH}$

Robitaille, Francois, OX

Rodríguez, J., 14

Romero, Pablo, 14

Saeys, Wouter, $1 \mathrm{G}$

Savary, Simon, 1C

Schmidt, R., OC

Schweizer, Stefan, 16

Serra, Catarina, 09, 1A

Sfarra, S., 06

Shepard, Steven M., OR

Shiryaev, V. V., OV

Siikanen, S., 17

Simões, Inês, 1A

Simões, Nuno, 09, 1 A

Singh, Bhavana, OJ

Spicer, James B., 11

Steudel, Franziska, 16

Stewart, Seán M., 1B

Tadeu, António, 09, 1 A

Tao, Guangming, OK

Theodorakeas, P., 04

Tragazikis, I., OY

Tremblay, Pierre, 1C

Trofimov, Vladislav $\mathrm{V} ., 1 \mathrm{H}$

Trofimov, Vyacheslav A., 1H

Tseng, Tzu-Liang (Bill), 1D

Varapula, Dharma T., ID

Vavilov, V.P., OQ, OV

Vergara, Germán, 14, $1 \mathrm{~F}$

Villamayor, Víctor, 14, 1F

Wagner, Florian, 16

Wang, Hongjin, Ol, OJ

Wang, Tung R., 05

West, Lucas, OX

Wilson, Kody A., 03

Winfree, William P., OD, OS

Yamada, H., 08, 0A

Yamada, S., 08

Zalameda, Joseph N., 02, OD, OS

Zeng, Fan W., 11

Zens, Timothy W. C., 03

Zhang, Hai, OX 


\title{
Conference Committees
}

\author{
Symposium Chair
}

Wolfgang Schade, Clausthal University of Technology (Germany)

and Fraunhofer Heinrich-Hertz Institute (Germany)

Symposium Co-Chair

Ming C. Wu, University of California, Berkeley (United States)

Conference Chair

Sheng-Jen (Tony) Hsieh, Texas A\&M University (United States)

Conference Co-Chair

Joseph N. Zalameda, NASA Langley Research Center (United States)

Conference Program Committee

Andrea Acosta, Colbert Infrared Services (United States)

Nicolas Avdelidis, National Technical University of Athens (Greece)

Paolo Bison, Consiglio Nazionale delle Ricerche (Italy)

Jeff R. Brown, Embry-Riddle Aeronautical University (United States)

Douglas Burleigh, La Jolla Cove Consulting (United States)

Fred P. Colbert, Colbert Infrared Services (United States)

K. Elliott Cramer, NASA Langley Research Center (United States)

Ralph B. Dinwiddie, Oak Ridge National Laboratory (United States)

Herbert Kaplan, Honeyhill Technical Company (United States)

Timo T. Kauppinen, VTT Technical Research Center of Finland (Finland)

Dennis H. LeMieux, Siemens Power Generation, Inc. (United States)

Monica Lopez Saenz, IRCAM GmbH (Germany)

Xavier P. V. Maldague, University Laval (Canada)

Gary L. Orlove, FLIR Systems, Inc. (United States)

Beata Oswald-Tranta, Montan University Leoben (Austria)

G. Raymond Peacock, Temperatures.com, Inc. (United States)

Piotr Pregowski, Pregowski Infrared Services (Poland)

Ralph A. Rotolante, Vicon Enterprises Inc. (United States)

Andres E. Rozlosnik, SI Termografía Infrarroja (Argentina)

Morteza Safai, The Boeing Company (United States)

Takahide Sakagami, Kobe University (Japan)

Steven M. Shepard, Thermal Wave Imaging, Inc. (United States)

Sami Siikanen, VTT Technical Research Center of Finland (Finland) 
Gregory R. Stockton, Stockton Infrared Thermographic Services, Inc.

(United States)

Vladimir P. Vavilov, Tomsk Polytechnic University (Russian Federation)

Xiong Yu, Case Western Reserve University (United States)

\section{Session Chairs}

1 Aerospace Applications

Xavier Maldague, University Laval (Canada)

Ralph B. Dinwiddie, Oak Ridge National Laboratory (United States)

2 Building Materials and Infrastructure Applications I

Jeff R. Brown, Embry-Riddle Aeronautical University (United States)

Beata Oswald-Tranta, Montan University Leoben (Austria)

3 Building Materials and Infrastructure Applications II

Beata Oswald-Tranta, Montan University Leoben (Austria)

Jeff R. Brown, Embry-Riddle Aeronautical University (United States)

4 Detector and Sensory System Development

Joseph N. Zalameda, NASA Langley Research Center (United States) Chien-Chon Chen, National United University (Taiwan)

$5 \quad$ NDT and Signal Processing

Steven M. Shepard, Thermal Wave Imaging, Inc. (United States)

Vladimir P. Vavilov, Tomsk Polytechnic University (Russian Federation)

6 NDT and Materials Evaluation I

Paolo Bison, Consiglio Nazionale delle Ricerche (Italy)

Junko Morikawa, Tokyo Institute of Technology (Japan)

$7 \quad$ Manufacturing and Processing Industries

Andres E. Rozlosnik, SI Termografía Infrarroja (Argentina)

Jian Chen, Oak Ridge National Laboratory (United States)

8 NDT and Materials Evaluation II

Takahide Sakagami, Kobe University (Japan)

Fred P. Colbert, Colbert Infrared Services, Inc. (United States)

9 Detection of Gas and Leaks

Vladimir P. Vavilov, Tomsk Polytechnic University (Russian Federation)

Michael Mauk, Drexel University (United States) 
10 Biological/Medical Applications

Timo T. Kauppinen, VTT Technical Research Center of Finland (Finland)

Ralph A. Rotolante, Vicon Infrared (United States)

Award Ceremony

Sheng-Jen Hsieh, Texas A\&M University (United States)

Joseph N. Zalameda, NASA Langley Research Center (United States)

Proc. of SPIE Vol. $9485948501-11$

Downloaded From: https://www.spiedigitallibrary.org/conference-proceedings-of-spie on 26 Apr 2023 Terms of Use: https://www.spiedigitallibrary.org/terms-of-use 
Proc. of SPIE Vol. $9485948501-12$

Downloaded From: https://www.spiedigitallibrary.org/conference-proceedings-of-spie on 26 Apr 2023 Terms of Use: https://www.spiedigitallibrary.org/terms-of-use 


\section{Introduction}

The SPIE ThermoSense conference promotes the worldwide exchange of information about Infrared (IR) imaging technology research and applications. Relevant technology areas include: thermography, thermal infrared sensing, IR imaging, measuring instruments, and non-destructive testing methods.

ThermoSense XXXVII built upon previous successful conferences and included emerging topics in sessions on NDT and Signal Processing, Biological and Medical Applications, and Infrared Detectors and System Development. Following are brief summaries of each session.

- Aerospace Applications: This session focused on the characterization of materials and components applied in aircraft industry using hybrid thermography, ultrasound, and/or optical imaging techniques. Topics included: coating, composites evaluation, and panel fatigue growth assessment.

- Building Materials and Infrastructure Applications: These sessions focused on characterization of building materials and structures using thermography and analytic modeling methods such as Finite Element Analysis (FEA). Approaches utilized included lock-in, pulse-phase, and modulated frequency thermography. Types of defects investigated include flaw size, crack depth, bubbles, and pin-holes. Materials and structures studied included building concrete, storage racks, optical film, and acrylic glass.

- Detector and Sensory System Development: This session focused on fabrication of detectors including: infrared fiber, logarithmic InGaAs, x-ray scintillator, and indium-antimony nanowires. Topics included a state-ofthe-art review of infrared fiber (invited paper), infrared system integration with detectors, and computational approach to enhancing thermal imaging.

- NDT and Signal Processing: This session consisted of four invited papers: Pulsed thermal NDT in tables, figures, and formulas [9485-26]; Advances in thermographic signal reconstruction [9485-27]; Principal component analysis for thermal image analysis [9485-28]; and Review of thermographic signal reconstruction [9485-29].

- NDT and Materials Evaluation: These sessions focused on materials evaluation utilizing hybrid non-destructive testing methods including laser ultrasound, thermal wave, C-scan, and microscope imaging. Materials of 
interest included carbon fiber, photonic hetero-structure, mild steel, and nuclear graphite.

- Manufacturing and Processing Industries: This session focused on welding processes, including spot-welding and laser beam welding process characterization.

- Detection of Gas and Leaks: Detection of gas and leaks is an important problem for public safety and national security. The oil and gas and chemical industries have very strict guidelines on gas release. Topics presented included combustion reaction, water spray transmission, gas and flame detection, seal contamination of packaged food, and microfluid system activation. Both multispectral and mid-wave infrared imaging techniques were applied.

- Biological/Medical Applications: This new session focused on applications of thermography in areas related to biology and medicine. Topics included a presentation of a 3D medical thermography device, applications of infrared imaging for mass screening, and use of thermography to track human body temperature.

The conference drew participants from many countries including: Spain, Portugal, Austria, Italy, Germany, Greece, France, Belgium, Ireland, Russia, Columbia, Chile, Belgium, Finland, Australia, Kazakhstan, Taiwan, Japan, Canada, and United States. This year, we had 46 papers and 52 presentations.

We would like to thank the authors, vendors, session chairs, ThermoSense steering committee, and SPIE technical staff who made this conference a success. Finally, we would like to acknowledge the support of Jay James, Vice President for Sales at FLIR Systems, Inc., for donating a FLIR ONE personal thermal imager as the Best Paper prize.

\section{Sheng-Jen (Tony) Hsieh Joseph N. Zalameda}

